\section{Synthesis of (S)-Sitagliptin}<smiles>C=CCCc1cc(F)c(F)cc1F</smiles>

$$
\begin{gathered}
\stackrel{\mathrm{NhO}_{2} \mathrm{~S}=\mathrm{S}=\mathrm{N}_{\mathrm{SO}_{2} \mathrm{Ph}}^{\mathrm{N}}}{\stackrel{\mathrm{P}^{2}(1.0 \text { equiv })}{ }} \\
\underset{\begin{array}{c}
\mathrm{Et} \mathrm{O}_{2} \mathrm{O}, 4^{\circ} \mathrm{C}, 12 \mathrm{~h} \\
(2.6 \mathrm{mmol} \text { scale }) \\
\text { ene reaction }
\end{array}}{\longrightarrow}
\end{gathered}
$$<smiles>O=S(=O)(N[S](C/C=C/Cc1cc(F)c(F)cc1F)NS(=O)(=O)c1ccccc1)Oc1ccccc1</smiles>

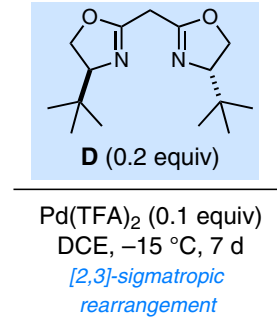
purified by filtration

\section{Key words}

sitagliptin

dipeptidyl dipeptidase-4

inhibitor

asymmetric allylic amination

palladium

ene reaction

$[2,3]$-sigmatropic rearrangement

1. 9-BBN (2.0 equiv) THF, $23^{\circ} \mathrm{C}, 1 \mathrm{~h}$;

then $\mathrm{NaOH}, \mathrm{H}_{2} \mathrm{O}_{2}$

2. $\mathrm{CrO}_{3}(0.13$ equiv)

$\mathrm{H}_{5} \mathrm{IO}_{6}$ (2.33 equiv)

$\mathrm{MeCN}-\mathrm{H}_{2} \mathrm{O}, 0{ }^{\circ} \mathrm{C}, 1 \mathrm{~h}$<smiles>C=C[C@H](Cc1cc(F)c(F)cc1F)NSc1ccccc1</smiles>

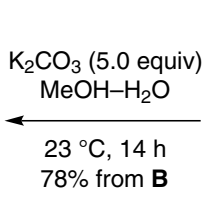<smiles>C=C[C@H](Cc1cc(F)c(F)cc1F)N(SP)SNS(=O)(=O)c1ccccc1</smiles>

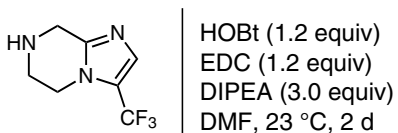

H (1.05 equiv) $\quad 75 \%$ (1.4 mmol scale)<smiles>O=C(C[C@@H](Cc1cc(F)c(F)cc1F)NSc1ccccc1)N1CCn2c(C(F)(F)F)cnc2C1</smiles><smiles>COCCOCCOc1ccccc1OC</smiles><smiles>N[C@@H](CC(=O)N1CCn2c(C(F)(F)F)cnc2C1)Cc1cc(F)c(F)cc1F</smiles>

Significance: Sitagliptin is a dipeptidyl dipeptidase-4 inhibitor that is prescribed for the treatment of type II diabetes. The small-scale synthesis depicted features a two-step construction of the allylic amine $\mathbf{E}$ involving an ene reaction using the sulfurdiimide $\mathbf{B}$ followed by a palladium-catalyzed asymmetric [2,3]-sigmatropic rearrangement of ylid $\mathbf{C}$.
Comment: The ylid $\mathbf{C}$ does not undergo a [2,3]sigmatropic rearrangement at $4{ }^{\circ} \mathrm{C}$ in the absence of the palladium catalyst. A further five 4-arylbut1-ene substrates with $\mathrm{F}, \mathrm{CF}_{3}$ and $\mathrm{OMe}$ substituents gave the allylic amination products in 79$94 \%$ yield and $81-94 \%$ ee.

SYNFACTS Contributors: Philip Kocienski 